\title{
THE TETRASPOROPHYTE OF SCINAIA JAPONICA SETCHELL (NEMALIALES-RHODOPHYTA)
}

\author{
$\operatorname{AUTHOR}(\mathrm{S})$ : \\ Umezaki, Isamu
}

\section{CITATION:}

Umezaki, Isamu. THE TETRASPOROPHYTE OF SCINAIA JAPONICA SETCHELL (NEMALIALES-RHODOPHYTA). PUBLICATIONS OF THE SETO MARINE BIOLOGICAL LABORATORY 1971, 19(2-3): 65-71

ISSUE DATE:

1971-10-30

URL:

http://hdl.handle.net/2433/175667

RIGHT: 


\title{
THE TETRASPOROPHYTE OF SCINAIA JAPONICA SETCHELL (NEMALIALES-RHODOPHYTA) ${ }^{1)}$
}

\author{
ISAMU UMEZAKI \\ Department of Fisheries, Faculty of Agriculture, Kyoto University, Maizuru
}

With Plates II-III and 25 Text-figures

On the basis of cytological investigations of Svedelius (1915) on Scinaia furcellata and of Kylin (1916) on Nemalion multifidum which showed that meiosis occurred in the carpogonium immediately following fertilization, the majority of Nemaliales in which tetrasporophytes are unknown have been considered to be haplobiontic. Recently, this was shown to be uncorrect by MAGNe (1961a, 1961b, 1964a, 1964b), who demonstrated cytologically that Lemanea, Nemalion and Scinaia produce carpospores and carpospore germlings which are diploid. BorLlot (1968), working on the life history of Scinaia furcellata in culture, has confirmed MAGNE's cytological results. She has found that carpospore germlings develop into dwarf, filamentous tetrasporophytes with which macroscopic gametophytes alternate. In recent years, corroborative studies have been made by von Stosan (1965) in Liagora farinosa, by FrIes (1967) in Nemalion multifidum, by Umezaki (1967) in N. vermiculare, and by Ramus (1969) in Pseudogloeophloea confusa. Thus, recent studies have demonstrated that some Nemaliales in which tetrasporophyte was not known possess an independent tetrasporophyte.

INOH (1947), who cultured carpospores of Scinaia japonica to an early stage of germlings, has supposed that the germlings must directly develop into gametophytes.

The present work was undertaken to study the life history of Scinaia japonica SETGHELL (Chaetangiaceae, Nemaliales) in which sporophyte is unknown.

\section{Material and Methods}

Scinaia japonica Setahelr grows on sandy bottom from a little below the low tide level to a depth of about 10 meters and it becomes fertile early in April at Shirahama, Wakayama Prefecture from where plants that were cultured were obtained.

A few cystocarpic plants were collected on April 3, 1968 at Shirahama and soon brought to the Department of Fisheries, Kyoto University at Maizuru, where the culture work was carried out.

1) Contributions from the Seto Marine Biological Laboratory, No.549.

Publ. Seto Mar. Biol. Lab., XIX (2/3), 65-71, 1971. (Article 6) 
Cystocarps of the female plant whose red-colored spots can be recognized with the naked eye are scattered over the whole length of the plant. On April 5, the plant bearing cystocarps was cut into pieces of about one centimeter length and cleaned in sterilized sea water to remove contaminated organisms. In order to make carpospores discharge cleaned pieces were placed in a watch-glass of a diameter of $7.5 \mathrm{~cm}$ in which there was sterilized sea water. After two or three hours carpospores were found discharged in the watch-glass. On the same day, the spores were transferred by a micropipette to glassslides placed at the bottom of a PETRI dish containing the enriched culture medium, SWII solution. On the next day, glassslides with carpospore germlings were again transferred into a glass-vessel with a volume of $250 \mathrm{ml}$ in which subsequent cultures were grown. The culture medium was replaced every ten days. For 40 days after germination the germlings were cultured at room temperature and under a daily $24 \mathrm{hr}$ illumination of day-light fluorescent lamps (500-1000 lux). Thereafter, from May 15 to July 10, the illumination intensity was changed to 1000-2000 lux and to a daily photoperiod of 8 hrs. During the summer season, from July 10 to September 20, cultures were controlled under conditions of $10-13^{\circ} \mathrm{C}$, a daily $24 \mathrm{hr}$ illumination, and about 500 lux. During the summer seasons of 1969 and 1970 the cultures were placed under the same conditions. After September 20 they were again cultured at room temperature and under a daily $24 \mathrm{hr}$ illumination (500-1000 lux). Under these conditions the filaments have remained alive. In order to induce formation of sporangia some cultures were submitted to other conditions (see below).

The author wishes to express his sincere thanks to Dr. I. A. Аввотт of the Hopkins Marine Station of Stanford University for her critical reading of the manuscript.

\section{Observations}

Most of the carpospores were discharged as a single spore or rarely as a chain of two, though the latter was separated soon (Text-figs. 1-4; PI. II, fig. 1). The discharged spores are irregular in shape and moved amoeba-like for a while or even for a week without fixing to the substratum. After settling, the spores became spherical with a

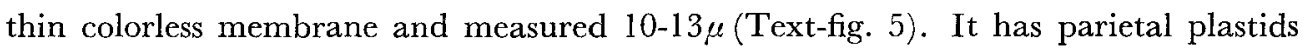
without pyrenoid. The fastened spores began to germinate soon. Two modes of spore germination were found. In one mode, the spore protruded a protuberance and the whole protoplasm of the spore moved to the elongated protuberance or germ tube (Text-figs. 6-12; Pl. II, fig. 2). In the other one, even after the elongation of a germ tube the protoplasm of the spore remained there and its spore body functioned as a living cell after that (Text-figs. 13, 14). There were no distinctions in regard to the subsequent development of filaments between the two types. After one week most of the germlings developed into several-celled filaments, some of them being branched (Textfigs. 9-12; Pl. II, fig. 3). In a ten-day old filament the emptied spore body began to disappear and a little later completely vanished (Text-fig. 12; Pl. II, figs. 4, 5). The young 


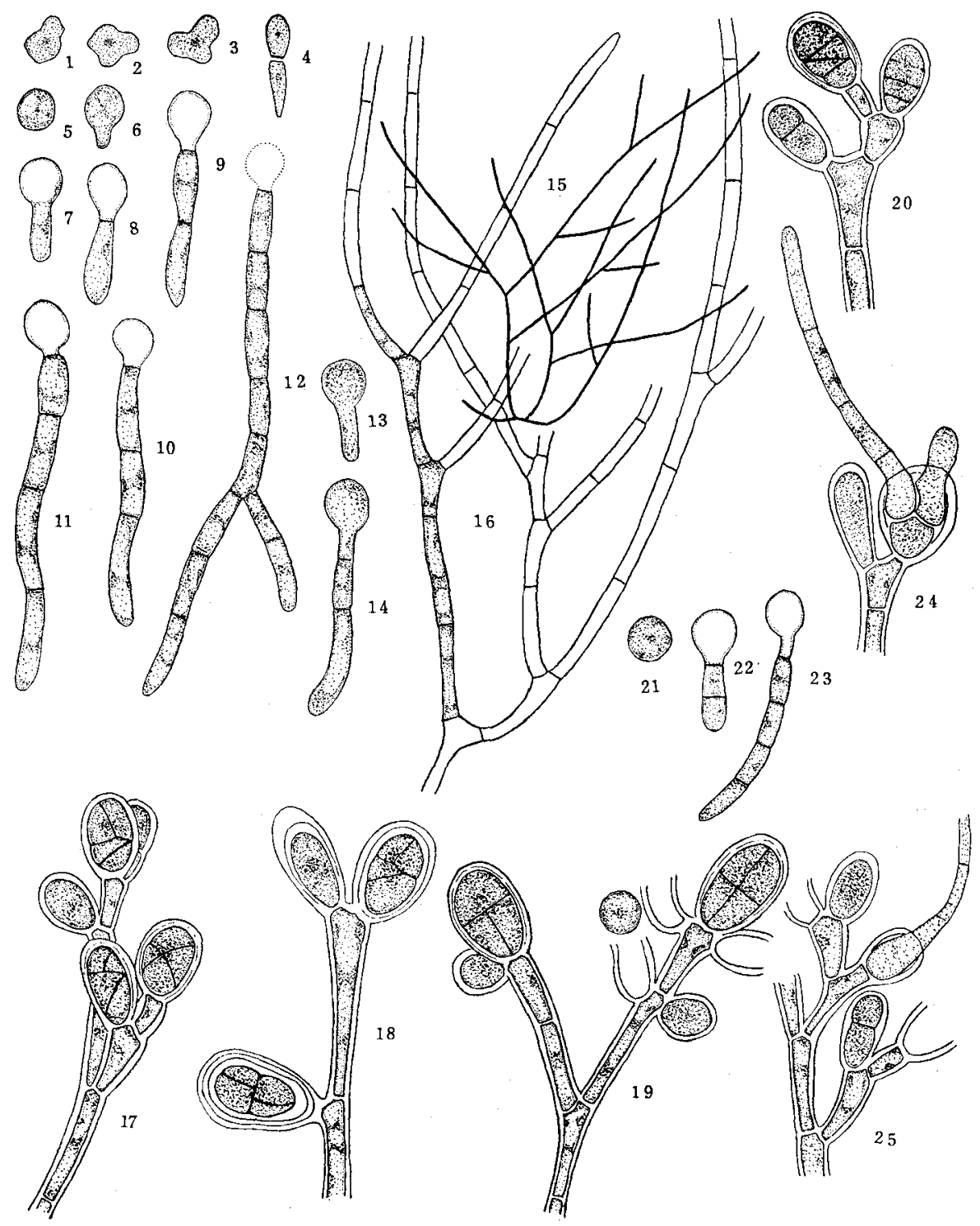

Figs. 1-3. Discharged carpospores showing amoeba-like irregular shape. Fig. 4. Discharged two-united carpospores. Fig. 5. Settled spherical carpospore. Figs. 6-12. Showing one type of spore germination in which spore contents migrate into germ tube; 6-7. Showing migration of spore contents into germ tube; 8-12. Successive development of a germling. Figs. 13-14. Showing the other type of spore germination in which spore contents remain in the spore body. Fig. 15. Habit of profusely branched Acrochaetium-like plant. Fig. 16. Part of a branched filament. Figs. 17-20. Tetrasporangia showing various division patterns; 17-18. Tetrasporangia which are divided in irregular cruciate and decussate manners; 19. Two tetrasporangia each of which is divided in cruciate manner; 20. Two tetrasporangia which are divided in zonate manner. Fig. 21. Tetraspore discharged from tetrasporangium. Figs. 22-23. Germlings of tetraspores. Figs. 24-25. Tetraspore germlings which germinated within the sporangium. Figs. 1-14. $\times 480$; Figs. $15 . \times 120$; Figs. 16-25. $\times 480$. 
filaments resemble in habit Acrochaetium-like plants, lacking colorless hairs. The cells of the filament are 4-7 $\mu$ thick, 25-45 $\mu$ long, 6-9(-10) times as long as the diameter. They have parietal plastids without pyrenoid (Text-fig. 16; Pl. II, figs. 5, 6). In twomonth cultures, or early in June of the year, the filaments became fertile, producing tetrasporangia on their terminal parts. Cultures, which had been placed under the following conditions, also became fertile. (1). On September 20, 1968, cultures, which, during the summer of the year, had been placed under a daily $24 \mathrm{hr}$ illumination (about $500 \mathrm{lux}$ ) at $10-13^{\circ} \mathrm{G}$, were transferred to differing the conditions (1000-2000 lux, a daily $24 \mathrm{hr}$ illumination, at room temperature). In nearly 50 days after that treatment or early in November sporangia were formed on the filaments. (2). On December 16, 1968, some cultures, which, after germination, had been maintained at $10-13^{\circ} \mathrm{C}$ and under a daily $24 \mathrm{hr}$ illumination of day-light fluorescent lamps (about 500 lux), were transferred near the window of a laboratory room and cultured at $20-23^{\circ} \mathrm{C}$ and under the natural light through the window. Nearly 35 days later or late in January 1969, the filaments became fertile. (3). On April 20, 1969, some cultures, which had been kept at room temperature and under a daily $24 \mathrm{hr}$ illumination of day-light fluorescent lamps (100-500 lux) during the winter season, were transferred near the window of a laboratory room and cultured at room temperature and under the natural light through the window. After nearly twenty days or late in May, the filaments also formed sporangia.

Formation of sporangia occurs on a terminal or a few terminal cells of the filament, or on newly branched short laterals, or branchlets bearing sporangia. In one case a terminal cell of the filament develops directly into a sporangium. In other cases a terminal cell of the filament enlarges itself and is divided by a wall into two cells, the upper cell becoming a sporangium and the lower a stalk. Sometimes, the stalk cell or its lower one or two cells issue directly one to three sporangia, forming a sporangial branchlet. Most of the tetrasporangia divided in typical cruciate manner, forming four spores (Text-fig. 19; Pl. III, figs. 3,4). Sometimes, four spores in a tetrasporangium are arranged in irregular cruciate or decussate ways (Text-figs. 17, 18; Pl. III, fig. 4). Rarely, irregularities showing zonate or irregular zonate arrangements were also found (Text-fig. 20; Pl. III, figs. 1, 2). The sporangia of these types were all found formed under the same condition of culture. The sporangium wall is at first thin, but later becomes thicker upon maturation, sometimes reaching a thickness of up to $9 \mu$. On maturation the top wall of a sporangium bursts and spores liberate. The empty sporangium, from which spores were discharged, sometimes regenerates itself and produces again a new sporangium within the old one (Pl. III, fig. 4). The discharged spores fall among the threads of the sporophyte and develop into filaments composed of several cells (Text-figs. 21-23). But the germlings develop no further. The discharged spores move amoeba-like as did the carpospores for a while and soon fasten to the substratum. The fastened spores are spherical, $10-12.5 \mu$ in diameter, a size equivalent to carpospores. The germination mode of spores is also similar to that of carpospores. Some- 
times spores do not leave the mother plant but germinate within the sporangium, developing into short filaments (Text-figs. 24, 25; Pl. III, figs. 5, 6).

\section{Discussion}

In culture, carpospores of Scinaia japonica germinate and develop into branched, filamentous, microscopic sporophytes bearing tetrasporangia. At early stages the filaments resemble in habit Acrochaetium-like plants, although they do not fit any known species of the genus Acrochaetium. Although the present work did not succeed to complete the entire life cycle of Scinaia japonica the alga should be considered as diplobiontic and heteromorphic: The well known alga in the sea represents the gametophyte and alternates with a dwarf, filamentous sporophyte. BoILlot (1968) has reported the tetrasporophyte of Scinaia furcellata in culture. Such a heteromorphic life history is demonstrated in Liagora farinosa by von STOSCH (1. c.), in Nemalion multifidum by Fries (1. c.), in N. vermiculare by Umezaki (1. c.), and in Pseudogloeophloea confusa by Ramus (1. c.). These findings clearly bear out the theory of MAGNE concerning the life histories of those species in the Nemaliales in which tetraporophyte was not known.

Division pattern of tetrasporangium is known as an important character for the classification of the red algae. However, the tetrasporangia of Pseudogloeophloea confusa (RAmus 1. c.) and Scinaia japonica (in the present paper) divide in all patterns (zonate, cruciate, decussate, tetrahedral, or irregular) known for the red algae. Similar irregularities are known in Liagora farinosa (Von STosch 1. c.), Nemalion vermiculare (UMezaki 1. c.), Chantransia dumontiae and Ch. polyblasta (Rosenvinge 1909), Acrochaetium pectinatum (WEST 1968), and the gonimoblast tetrasporangia of Liagora papenfussii (as L. pinnata, YAMADA 1938). These findings show that division pattern of tetrasporangium is no great significance for the classification of some families in the Nemaliales.

Formation of sporangia on the sporophyte is dependent on temperature and light conditions. When cultures, which had been placed at low temperature $\left(10-13^{\circ} \mathrm{C}\right)$ and under weak illumination of light (100-500 lux), have been cultured at comparatively higher temperature $\left(20-23^{\circ} \mathrm{C}\right)$ and under more intensive illumination of light or under the natural light exposure in late autumn, winter, or early spring seasons the formation of sporangia was induced. Such a high light and temperature demand for tetrasporangium formation has been suggested by the results of experiments by FrIEs (1967) in Nemalion multifidum, by UMEZAKI (1967) in $N$. vermiculare, and by RAmus (1969) in Pseudogloeophloea confusa. In the last species nitrate depletion induced also the formation of tetrasporangia (Ramus l. c.).

\section{Summary}

The life history of Scinaia japonica Setchell (Chaetangiaceae, Nemaliales) has been studied in culture. The carpospore germlings gave rise to dwarf, branched filaments of which the young stages resemble superficially the Acrochaetium-Rhodochorton 
complex. The filaments formed tetrasporangia on them. The tetrasporangia are divided usually in cruciate manner, forming four tetraspores. Sometimes, irregularities of four spores in a tetrasporangium were found. They are arranged in irregular cruciate, decussate, zonate, or irregular zonate ways. The tetraspores discharged germinated and developed into filaments of one row of several cells. The germlings did not develop further.

The sporangial formation on the sporophyte was induced when cultures, which had been under weak illumination of light and at low temperature, were placed at comparatively higher temperature and under comparatively more intensive illumination of light.

Although the present work did not succeed in completing the life cycle of Scinaia japonica, it seems that the alga is diplobiontic and heteromorphic: One is a well known Scinaia gametophyte which is haploid and other is a dwarf sporophyte which is diploid.

\section{REFERENGES}

Boillot, A. 1968. Sur l'existence d'un tetrasporophyte dans le cycle de Scinaia furcellata (TurNER) Bivona, Nemalionales. C.R. Acad. Sci. Paris, Ser. D, 266: 1831-1832.

Fries, I. 1967. The sporophyte of Nemalion multifidum (Weber \& MolnR). J. Ag. Svensk Botan. Tidskr. $61(4): 457-462$.

INOH, S. 1947. Development of Marine Algae. 255 pp. Tokyo.

KyLIN, H. 1916. U̇ber die Befruchtung und Reduktionsteilung bei Nemalion multifidum. Ber. deutsch. bot. Ges. 34: 257-271.

Magne, F. 1961a. Sur le cycle cytologique du Nemalion helminthoides (Veliey) Batters. C.R. Acad. Sci. Paris, Ser. D, 252: 157-159.

Magne, F. 1961b. Sur la caryologie de deux Rhodophycées considerées jusqu'ici comme a cycle cytologique extiérement haplophasique. C.R. Acad. Sci. Paris, Ser. D, 252: 4023-4024.

MAGne, F. 1964a. Les Rhodophycées a cycle haplophasique existent-elles? Fourth Int. Seaweed Symp. (1961) Proc.: 112-116.

Magne, F. 1964b. Recherches caryologique chez les Floridées (Rhodophycées). Cah. Biol. Mar. 5: $461-671$.

Ramus, J. 1969. The developmental sequence of the marine red alga Pseudogloeophloea in culture. Univ. Calif. Publ. Bot. 52: 1-42.

Rosenvinge, L. K. 1909. The marine algae of Denmark. Contributions of their natural history. Pt. 1. Introduction, Rhodophyceae I. K. danske Vidensk. Selsk. Skr. 7. Raekke Nat. math. Afd. 7: $1-150$.

Svedelius, N. 1915. Zytologisch-entwicklungsgeschichtliche Studien über Scinaia furcellata. Nova Acta Soc. Upsal., Ser. IV, 4(4): 1-55.

Umezaki, I. 1967. The tetrasporophyte of Nemalion vermiculare Suringar. Revue Algol., N. S. 9(1): 19-24.

von Stosch, H. A. 1965. The sporophyte of Liagora farinosa Lamour. Br. Phycol. Bull. 2(6): 486-496. WEST, J. A. 1968. Morphology and reproduction of the red alga Acrochaetium pectinatum in culture. J. Phycol. 4: 89-99.

Yamada, Y. 1938. The species of Liagora from Japan. Sci. Rep. Inst. Algol. Res., Hokkaido Univ. $2: 1-34$. 


\section{EXPLANATION OF PLATES II-III}

Plate II. Carpospores of Scinaia japonica and their development after germination. Fig. 1. Discharged carpospores. $\times 100$. Fig. 2. Germination of carpospores from which germ tube is protruded. $\times 600$. Figs. 3-6. Various stages in development of sporophyte filament. Figs. 3-4. $\times 200$; Fig. 5. $\times 150$; Fig. $6 . \times 650$.

Plate III. Formation of tetrasporangia on the sporophytes of Scinaia japonica. Fig. 1. One tetrasporangium which is divided in zonate manner. $\times 600$. Fig. 2. One tetrasporangium which is divided in zonate manner, three young sporangia, and one sporangium regenerating from the old one. $\times 600$. Fig. 3. One tetrasporangium which is divided in cruciate manner, two young sporangia, and one empty one. $x$ 600. Fig. 4. Three tetrasporangia of which top one is cruciately divided and other two are divided in irregular cruciate manner, and regeneration of empty sporangium in which new sporangium is produced. $\times 600$. Figs. 5,6 . Germination of tetraspore within the tetrasporangium. $\times 500$. 
Publ. Seto Mar. Biol. Lab., XIX (2/3), 1971.

PLATE II
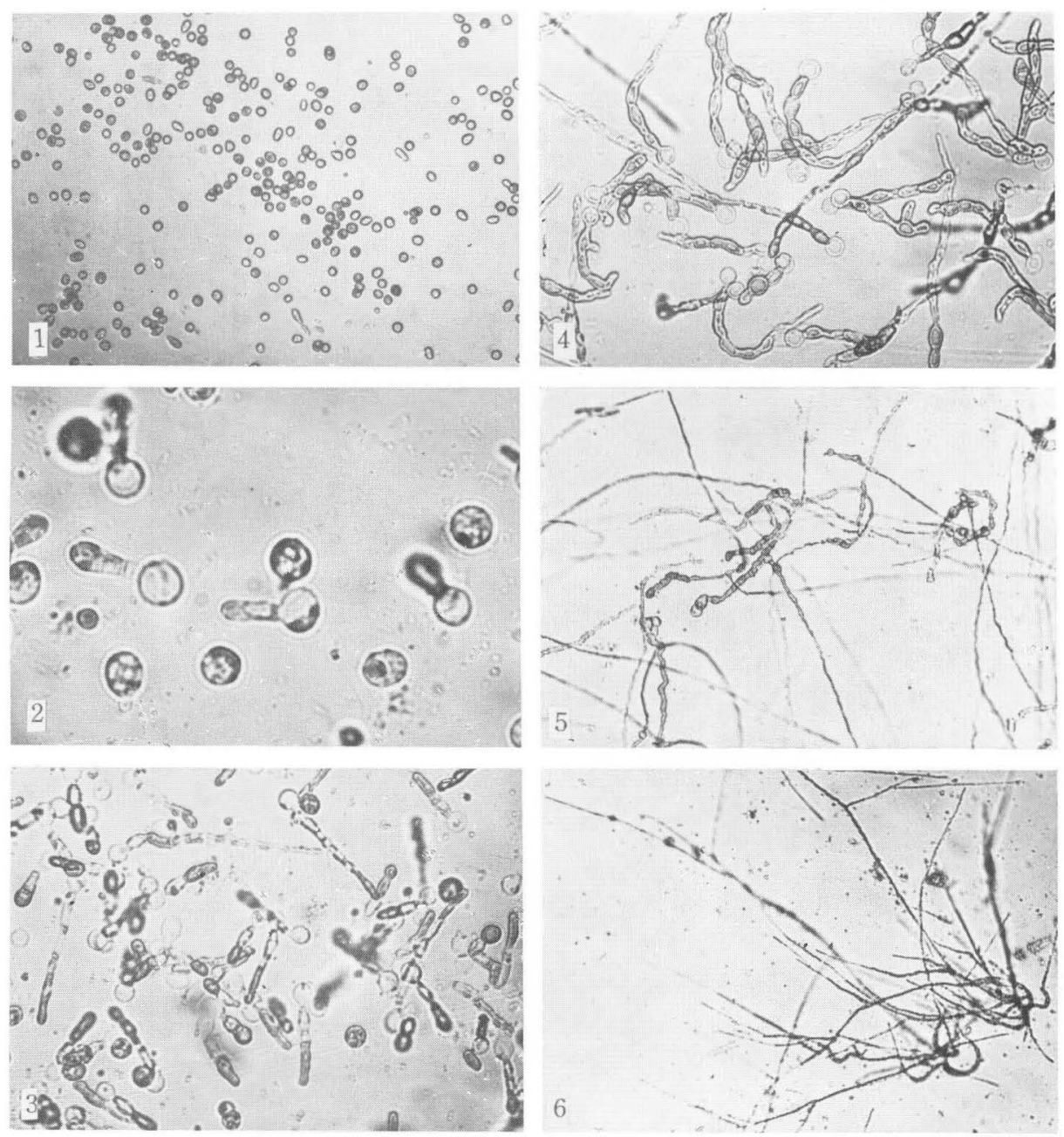

I. UMEZAKI: Tetrasporophyte of Scinaia japonica 
Publ. Seto Mar. Biol. Lab., XIX (2/3), $1971 . \quad$ PlATE III
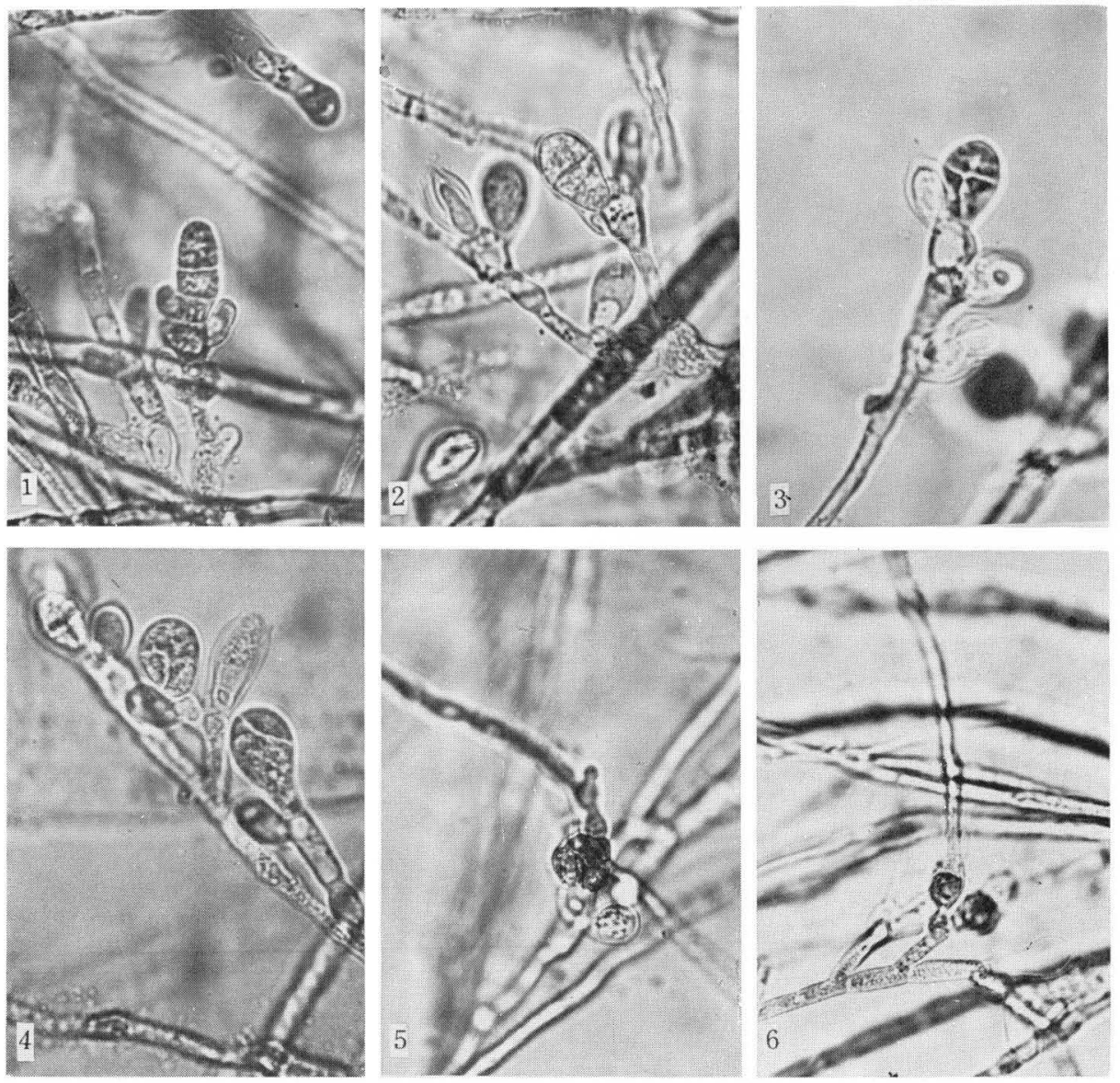

I. UMEZAKI : Tetrasporophyte of Scinaia japonica 